\title{
Filosofiese Plasing van die Fundering
}

Immanuel Kant (1724-1804) se filosofie word gewoonlik in die sogenaamde voorkritiese en kritiese periodes ingedeel. Die voorkritiese periode begin met Kant se eerste publikasie in 1847: Gedanken von den wahren Schätzung der lebendigen Kräfte in der Natur (Gedagtes oor die ware beoordeling van die lewende kragte in die natuur), wat baie sterk onder aie invloed van Isaac Newton staan. Kant promoveer in 1755 met 'n proefskrif getitel Abhandlung über das Feuer (Verhandeling oor vuur) en habiliteer in dieselfde jaar met ' $n$ verhandeling oor Prinzipien der metaphysischen Erkenntnis (Prinsipes van metafisiese kennis).

In die volgende vyftien jaar verskyn ' $n$ lang lys publikasies oor ' $n$ groot verskeidenheid onderwerpe. Die mense wat die grootste invloed op sy denke uitgeoefen het, was Isaac Newton (1643-1727), Gottfried Wilhelm Leibniz (1646-1716), Christian Wolff (1679-1754), John Locke (1632-1704), David Hume (1711-1776), die Graaf Shaftesbury (1671-1713) en Jean-Jacques Rousseau (1712-1778). Hoewel Kant met sy voorkritiese geskrifte groot bekendheid verwerf het, toon dit tog in 'n groot mate ' $n$ onvastheid van koers, en kan.'n mens in individuele geskrifte die invloed sien van die denkers met wie Kant hom op daardie tydstip besig gehou het. Tog kan ' $n$ mens duidelik sien dat Kant besig is om hom ten opsigte van die natuurwetenskap en wysbegeerte van sy tyd te oriënteer. Waar die natuurwetenskap aanvanklik sy aandag die meeste besig hou, kom wysgerige besinning algaande sterker na vore. Teen die eir.de van die voorkritiese periode word dit baie duidelik dat hy bewus geword het van die problematiek waarmee hy in die kritiese periode gaan besig bly en dat sy eie filosofie al sterker vorm begin aanneem. 
Die kritiese periode begin in 1770. In hierdie jaar word Kant as professor aan die Universiteit van Königsbergen benoem en sy intreerede dra die titel: De mundi sensibilis atque intelligibilis forma et principii (Aangaande die vorm en beginsels van die sensibele (sinlike) en die intelligibele (rasionele) wêreld). In hierdie rede kondig hy die program van sy kritiese filosofie aan.

Met die kritiese filosofie slaan Kant 'n fundamenteel verskillende rigting in. 'Kritiek' beteken vir Kant die aanwys van tekortkominge, maar dit is nie die wesenlik belangrike nie. Kritiek het eers werklik betekenis wanneer nie net die foute aangewys is nie, maar die korrekte in die plek van die foutiewe gestel is. Dit lei daartoe dat die kritiek van besondere filosowe of filosofiese rigtings by Kant ' $n$ geringe rol speel. Kritiek kry eintlik die betekenis van fundering, wat moet aantoon wat die gronde is waarop kennis (wat filosofie insluit) gebou moet word. Om hierdie rede kry ons dikwels ' $n$ formulering wat aanvanklik vreemd lyk, naamlik: Hoe is (kennis, wetenskap, sinteties aprioriese oordele ens) moontlik?

Met die moontlikheidsvraag dui hy sy soeke na die laaste gronde aan. Volgens Kant het 'n mens drie basiese vermoëns, naamlik denke, wil en gevoel. Hierdie driedeling kom reeds van die Grieke af en word in Kant se tyd in die psigologie van Tetens uitgewerk. Ook van die Grieke af kom die oortuiging dat die mens wesenlik ' $n$ rasionele wese is en dit geld vir Kant vanselfsprekend. Hierdie rede as vermoë om bewus en logies var iets kennis te neem, is net die een rede in elke mens en is in sy wesenlike trekke universeel. Dit beteken dat wetenskap (die rede in sy kennende funksie), etiek (die rede funksioneel in wil en sedelike beoordeling) en estetiek (die rede in sy kennisname en beoordeling van emosionele belewenisse) elkeen in sy eie reg en met sy eie beginsels bestaan, maar aat dit tog ' $n$ fundamentele eenheid vorm deur die feit dat dit een en dieselfde rede is wat op aldrie gebiede beweeg. Die wetenskaplike rede (wat hy ook die spekulatiewe of 
teoretiese rede noem) kan nie etiese of estetiese vrae beantwoord of aan die etiek en estetiek voorskryf nie, maar daar mag ook geen botsing voorkom nie. Waar die Rasionalisme voor Kant die rede beskou as in staat tot die beantwoording van alle vrae op elke terrein, daar vereis die moontlikheidsvraag dat die filosoof moet vasstel of die rede werklik in staat is om die vrae te beantwoord. Daar moet met ander woorde in die kritiek die grense van die rede aangewys word ( $\mathrm{vgl}$ byvoorbeeld KrV: XXIV).

Die onderskeiding van denke, wil en gevoel bring mee dat Kant se drie hoofwerke in hulle titels duidelike verwantskap toon: Kritik der reinen Vernunft (1781), Kritik der praktischen Vernunft (1788) en Kritik der Urteilskraft (1790). Die $K r V$ is Kant se eerste belangrike publikasie na 1770, maar daarna het die publikasies vinnig gevolg. Terwyl die drie Kritieke as 't ware die drie merkers van die reeks publikasies is, het daartussen talle publikasies met ' $n$ verskeidenheid titels oor die drie gebiede verskyn.

Van 1770 af het Kant se filosofie weinig verander. In sy professorale intreerede het Kant 'n program aangekondig en van 1781 af, toe die $K r V$ verskyn het, voer hy die program uit. Afgesien van 'n aantal geskrifte wat in 'n sterk mate los staan en op besondere temas toegespits is, volg sy filosofie ' $n$ vaste patroon.

Die ruimte ontbreek om 'n oorsig van Kant se filosofie te maak. Ons kan egter sê dat daar voor Kant twee hoofstrominge van filosofie was, naamlik die (hoofsaaklik Britse) Empirisme en die (hoofsaaklik Vastelandse) Rasionalisme. Albei strominge kan egter as Aufklärungfilosofie beskou word waarin na ware, gefundeerde, betroubare, rasionele kennis gestreef is. Vir die Empiriste was sulke kennis net deur middel van die sintuie verkrygbaar (dit wil sê ervaringskennis, wat Kant aposterioriese kennis noem). Die Rasionaliste het ervaringskennis as onbetroubaar, relatief en veranderlik beskou en het ware kennis in die rede gesoek. Volgens die Rasionaliste was die basiese begrippe aange- 
bore en ware kennis het 'n mens bereik deur die analise van hierdie begrippe. Die wiskunde was hulle ideale wetenskap.

Vir Kant was dit voor die hand liggend dat albei sieninge eensydig is. Die kombinasie van die twee was egter nie net ' $n$ kwessie van die een plus die ander nie. Die regte begrip van kennis moet ' $n$ volkome eenheid van die rasionele en die empiriese uitdruk. Dit verkry Kant deur van die Empirisme te aanvaar dat kennis van die werklikheid slegs deur ervaring verkry kan word; die Rasionalisme met sy analise van die aangebore begrippe kan nooit verder kom as juis daardie begrippe nie; daarbenewens bring die loslaat van die ernpirie inee dat daar behalwe die reëls van die logika geen wyse is : Naarop die spekulatiewe hantering van die begrippe aan bande gelê kan word nie. Die Empirisme kan op sy beurt nie bo die toevalligheid van die individuele gegewenheid uitstyg nie. Die kenmerke van wetenskaplike uitsprake is juis die volstrekte algemeenheid en noodwendigheid daarvan, wat die formulering van natuurwette moontlik maak. Hierdie volstrekte algemeenheid en noodwendigheid is juis die kenmerk van die suiwer rasionele besluite. In Kant se terme kan ons sê:

* Elke oordeel bestaan uit 'n subjek, predikaat en koppelterm.

* Die verhouding tussen subjek en predikaat is analities wanneer die predikaat reeds in die subjek opgesluit lê, sinteties wanneer die predikaat nie in die subjek opgesluit lê nie, maar van elders deur ervaring verkry is.

* 'n Empiriese of aposterioriese oordeel is altyd sinteties, ' $n$ analitiese oordeel altyd apriories. 
* Van al die moontlike kombinasies lewer net die sinteties aprioriese oordele ' $n$ probleem op: Omdat dit apriories is, is dit onafhanklik van die ervaring; omdat dit sinteties is, is die predikaat nie reeds in die subjek opgesluit nie. Waarvandaan kom die predikaat dan?

* Kant se oplossing is: Die oordeel is sinteties omdat die inhoud wat in die predikaat vervat is, uit die ervaring kom; dit is apriories omdat die rede ' $n$ algemene (universele) en noodwendige vorm aan die oordeel gee. Algemeenheid en noodwendigheid sluit mekaar in. Hierdie vorm is dus van die rede afkomstig en Kant onderskei die aanskouingsvorme van ruimte en tyd aan die een kant, en die denkkategorieë aan die ander kant. Die rede is dus nie passief soos in die Empiriste meen nie, maar aktief. Ruimte en tyd is die vorme waarin alle gewaarwordinge gegiet word; die twaalf kategorieë is die fundamentele wyses waarop die gewaarwordinge deur die rede verwerk word.

Hierdie basiese strukture werk Kant in die $K r V$ uit, asook die gebruik en implikasies daarvan in die teoretiese gebruik van die rede. Hoewel hy hier ook oor wil en gevoel (etiek en estetiek) basiese opmerkings maak (wat die $K r V$ Kant se omvangrykste werk maak), werk hy die toepassing daarvan in sy etiese werke en die Kritik der Urteilskraft uit.

Nog 'n taak van die $K r V$ is om aan te toon dat die teoretiese rede grense het: Aan die een kant is dit begrens in die rigting van die metafisika, sodat die rede hom nie aan ongebreidelde, ongekontroleerde spekulasie skuldig sal maak nie. Hierdie begrensing word gedoen deur die noodwendige verbondenheid aan die ervaring. Aan die ander kant word dit begrens in die rigting van die etiek en die estetiek, omdat 
hierdie twee dissiplines elkeen met 'n eiesoortige gebied en problematiek werk. Op elkeen van hierdie gebiede is die beginsels wat in die $K$ $r V$ neergelê is, ook geldig, maar nie op so ' $n$ wyse dat dit die etiese en estetiese beginsels moet steun of bewys nie, maar wel so dat die etiese en estetiese beginsels nie met die teoretiese mag bots nie.

Kant werk sy etiek hoofsaaklik in vier werke uit, naamlik Fundering, $K p V, M d S$ en die vierde werk wat eers in 1924 ter herdenking van sy tweehonderdste geboortedag onder die titel van Vorlesungen über die Ethik verskyn, saamgestel uit die klasaantekeninge van 'n paar van Kant se studente.

Van hierdie vier is die Fundering die belangrikste. Hierin werk Kant die beginsels van sy etiek uit. Die res van sy etiese werke bestaan hoofsaaklik uit die verdere uitwerk en illustrasie van sy beginsels en die toepassing daarvan in die regsfilosofie, staatsleer en so meer. Die Fundering is dan ook die invloedrykste van al Kant se werke, minstens net so invloedryk as die $K r V$. 